\title{
The Alberta smoke plume observation study
}

\author{
Kerry Anderson ${ }^{1}$, Al Pankratz ${ }^{2}$, Curtis Mooney ${ }^{2}$, and Kelly Fleetham ${ }^{3}$ \\ ${ }^{1}$ Natural Resources Canada, 5320122 Street, Edmonton, Alberta T6H 3S5, Canada \\ ${ }^{2}$ Environment and Climate Change Canada, 925049 Street, Edmonton, Alberta T6B 1K5, Canada \\ ${ }^{3}$ Alberta Agriculture and Forestry, 9920108 Street, Edmonton, Alberta T5K 2M4, Canada
}

Correspondence: Kerry Anderson (kerryanderson@ shaw.ca)

Received: 29 August 2017 - Discussion started: 9 October 2017

Revised: 22 December 2017 - Accepted: 8 January 2018 - Published: 22 February 2018

\begin{abstract}
A field project was conducted to observe and measure smoke plumes from wildland fires in Alberta. This study used handheld inclinometer measurements and photos taken at lookout towers in the province. Observations of 222 plumes were collected from 21 lookout towers over a 6-year period from 2010 to 2015. Observers reported the equilibrium and maximum plume heights based on the plumes' final levelling heights and the maximum lofting heights, respectively.

Observations were tabulated at the end of each year and matched to reported fires. Fire sizes at assessment times and forest fuel types were reported by the province. Fire weather conditions were obtained from the Canadian Wildland Fire Information System (CWFIS). Assessed fire sizes were adjusted to the appropriate size at plume observation time using elliptical fire-growth projections.

Though a logical method to collect plume observations in principle, many unanticipated issues were uncovered as the project developed. Instrument limitations and environmental conditions presented challenges to the investigators, whereas human error and the subjectivity of observations affected data quality. Despite these problems, the data set showed that responses to fire behaviour conditions were consistent with the physical processes leading to plume rise.

The Alberta smoke plume observation study data can be found on the Canadian Wildland Fire Information System datamart (Natural Resources Canada, 2018) at http://cwfis.cfs.nrcan.gc.ca/datamart.
\end{abstract}

\section{Introduction}

Some of the most severe air quality events in Canada are due to smoke from forest fires. Each year dozens of communities are evacuated due to smoke and health concerns, each evacuation disrupting the lives and livelihoods of residents, their families, and their communities. Large-scale smoke events can blanket major population centres affecting hundreds of thousands of people, of whom approximately one-third are susceptible (Stieb et al., 2018). Recent examples of significant smoke events that triggered provincial health advisories include the following:

- May 2001, when a plume from the Chisholm fire inundated Edmonton, causing particulate matter readings to reach a concentration of approximately $260 \mu \mathrm{g} \mathrm{m}^{-3}$, compared to a daily average near $12 \mu \mathrm{g} \mathrm{m}^{-3}$.
- 13 July 2012, when Alberta Health Services issued a precautionary health advisory regarding air quality in Edmonton due to fires from the $\mathrm{BC}$ interior. Later that summer, on 24 September, Alberta Health Services issued a smoke advisory for the Edmonton area due to fires in northern Alberta.

- June to August 2014, which was reputed to be the worst forest fire season the Northwest Territories had experienced for at least two decades. The smoke generated by the fires was blown into the Prairie provinces and created a moderate health risk, leading Environment Canada to declare an air quality advisory for southern Saskatchewan and Manitoba on 9 July.

- 5 July 2015, when Metro Vancouver issued an air quality advisory for smoke from fires on British Columbia's 
Sunshine Coast, $50 \mathrm{~km}$ northwest of the city. This smoke enveloped greater Vancouver, the Lower Mainland Fraser Valley, and Vancouver Island.

- July 2015, when Saskatchewan fires and smoke resulted in the evacuation of over 13000 people in the La Ronge region and prompted health officials in Saskatchewan and neighbouring Manitoba to issue health advisories due to smoke.

- August and September 2015, when smoke from the Okanogan Complex fire in Washington state extended through much of the BC interior, affecting cities such as Penticton and Kelowna. On 26 August, Alberta Health Services issued air quality advisories for areas from the US border north to the Edmonton region because of smoke from these wildfires.

These are recent examples of smoke events that may only get worse given the potential increase of wildland fire activity due to global warming. Flannigan et al. (2009) describe how fire occurrence and area burned are likely to increase due to climate change, while the fire season is expected to broaden in the temporal and boreal forests.

A challenge in forecasting smoke events is predicting its transport and, more specifically, the height to which a plume will rise. Drastically different trajectories can result if a plume breaks through into the free atmosphere compared to a plume that is confined within the mixing layer. Predicting the possible penetration (or injection) heights of smoke plumes from wildland forest fires is largely an unresolved problem (Heilman et al., 2014; Goodrick et al., 2013; Larkin et al., 2012). Until now, most approaches have followed those of air pollution plumes generated from tall industrial chimneys (Briggs, 1965). This is despite the fact that a chimney plume acting as a low heat-flux point source is a poor analog to a wildland fire acting as a high heat-flux source covering a broad area.

Modelling wildland fire smoke plumes is a relatively new research topic and one that mixes a variety of disciplines. A forest fire's behaviour drives the processes that lead to smoke emissions and concentrations while the energy generated by the fire leads to the buoyancy, vertical lift, and plume penetration height. Several models have been developed, ranging from simple, empirical approaches (Harrison and Hardy, 2002) to others involving full physics (Freitas et al., 2007), yet there is a lack of observational data to evaluate such models.

The following studies used remotely sensed data to evaluate smoke plume predictions:

- BlueSky, a widely accepted smoke forecasting framework (Larkin et al., 2009), uses satellite and ground reports for fire size and emissions and the Briggs model for plume rise. Rolph et al. (2009) used the BlueSky system to evaluate the National Oceanic and Atmospheric Administration's (NOAA) Smoke Forecasting
System (SFS). Fire reports were based on satellitedetected hotspots from the Geostationary Operational Environmental Satellite (GOES)and NOAA Advanced Very High Resolution Radiometer (AVHRR). Raffuse et al. (2012) compared smoke plume heights produced by BlueSky to Multi-angle Imaging SpectroRadiometer (MISR) data.

- Val Martin et al. (2010) compared fire radiative power (FRP) from the Moderate Resolution Imaging Spectroradiometer (MODIS) and plume heights from MISR for fires in North America from 2002 to 2007.

- Sofiev et al. (2009) described a new approach to plume rise and evaluated it and other plume-rise models using MODIS and MISR data (Sofiev et al., 2012).

While quality work, these studies lack ground observations of fire behaviour characteristics (fire size, growth, and intensity). Satellite-based information cannot substitute for ground observations as satellites do not provide an accurate measure of fire size due to instrument resolution. Likewise, FRP measurements do not discern between small, highintensity fires and larger, low-intensity fires at the sub-pixel level of the satellite resolution. Finally, the timing of satellite passes is an issue, as often these do not occur in the mid- to late afternoon when fire intensity is at its maximum. These factors are important to determine the size and shape of the plume, leading to the volume of the smoke column.

There have been plume studies involving detailed groundbased observations. Liu et al. (2010) compared their Daysmoke model to a prescribed burn in Tennessee in 2006. Achtemeier et al. (2011) expanded this study to seven and Liu et al. (2013) to twenty prescribed burns in the southeastern US. Lavrov et al. (2006) used measurements from a light detection and ranging (lidar) device to test smoke plume predictions using their PHOENICS fluid dynamics model for an experimental shrub-fire burn in Portugal. Kovalev et al. (2009) described a technique for using a mobile lidar, which was later used by Lareau and Clements (2016) to study two pyrocumulus clouds. Extensive ground information was included in these various studies but either the limited sample size of the lidar studies or the low intensity of the prescribed burns prevented using these in a rigorous evaluation of plume-rise models of high-intensity wildfires.

This study describes a field project conducted to observe and measure the smoke plumes from wildland fires in Alberta. Observers at several lookout towers in the province used handheld inclinometers to take height measurements of smoke plumes. Plume observations were then linked to ground-based fire reports to capture fire weather and fire behaviour associated with the plumes and include them in the data set. The overall purpose of this study was to create an extensive data set composed of ground-based observations of smoke columns and related fire information to validate 
Table 1. Lookout towers used in Alberta smoke plume observation study.

\begin{tabular}{lrrr}
\hline Name & Latitude & Longitude & $\begin{array}{r}\text { Platform } \\
\text { elevation } \\
\text { (m a.s.1.) }\end{array}$ \\
\hline Battle River & 57.17 & -117.66 & 674 \\
Hawk Hills & 57.66 & -117.42 & 730 \\
Heart Lake & 54.91 & -111.34 & 866 \\
Hotchkiss & 57.33 & -118.96 & 990 \\
Jean Lake & 57.50 & -113.88 & 745 \\
Kakwa & 54.42 & -118.98 & 1230 \\
Keg & 57.64 & -118.35 & 980 \\
Livock & 56.46 & -113.02 & 650 \\
May & 55.56 & -112.40 & 866 \\
Muskeg Mountain & 57.14 & -110.89 & 615 \\
Petitot & 59.52 & -119.61 & 780 \\
Pinto & 54.78 & -119.40 & 1044 \\
Ponton & 58.93 & -116.22 & 954 \\
Rainbow Lake & 58.35 & -119.71 & 601 \\
Rock Island Lake & 55.33 & -113.46 & 722 \\
Saddle Hills & 55.62 & -119.72 & 967 \\
Teepee Lake & 56.46 & -114.12 & 782 \\
Trout Mountain & 56.80 & -114.42 & 826 \\
Wadlin & 57.78 & -115.46 & 848 \\
White Mountain & 55.69 & -119.24 & 1021 \\
Whitefish & 56.18 & -115.47 & 735 \\
\hline
\end{tabular}

a plume-rise model the authors are developing to improve smoke forecasting models (Anderson et al., 2011).

\section{Methodology}

The Alberta smoke plume study included 222 plume observations collected over a 6-year period from 2010 to 2015 (20, 10, 26, 29, 63, and 74 observations per year chronologically), involving 21 fire observation lookout towers (Table 1). Observations were tabulated at the end of each year and matched to reported fires. Fire sizes at assessment times and forest fuel types were recorded by the province. Fire weather conditions were obtained from the Canadian Wildland Fire Information System (CWFIS). Finally, assessed fire sizes at reported times were adjusted to sizes at plume observation times using elliptical fire-growth projections.

\subsection{Plume height observations}

The wildfire branch of Alberta Agriculture and Forestry runs a network of about 127 lookouts (many of which are towers) for the detection of wildland fires. Observers at these towers monitor the forest and are well trained in recognizing plumes from wildland fires, reporting the azimuth for fire detection purposes. Two tower reports are used to triangulate to the fire location. Also, fire suppression resources report the precise location upon arrival using the Global Position System

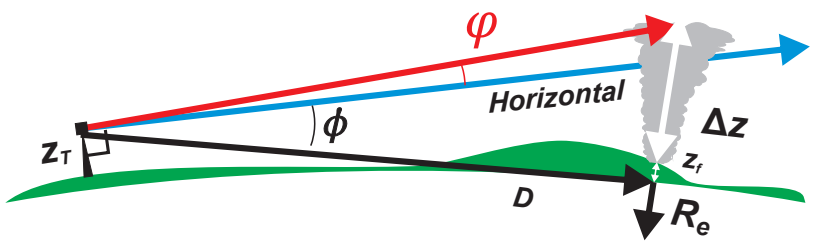

Figure 1. Illustration of the plume height observation $(\Delta z)$, the tower height $\left(z_{\mathrm{T}}\right)$, the fire height $\left(z_{\mathrm{f}}\right)$, the distance to the fire $(D)$, measured inclinometer angle $(\varphi)$, and horizon angle $(\phi$, accounting for the curvature of the Earth with radius $=R_{\mathrm{E}}$ ).

(GPS). From this and the lookout tower location, distance to the fire can be ascertained.

During the 6-year study, these observers were asked to take measurements using a handheld Suunto PM-5 inclinometer. The inclinometer used is a simple device, providing measurements in degrees above or below a level handheld position. The device has a manufacturer specification of $\pm 0.25^{\circ}$ accuracy with $0.5^{\circ}$ gradation intervals. Based on this, one would expect a $\pm 4.36 \mathrm{~m}$ accuracy in measurements of plume heights at $1 \mathrm{~km}$ distance, $\pm 43.6 \mathrm{~m}$ accuracy at $10 \mathrm{~km}$ distance, and $\pm 436 \mathrm{~m}$ accuracy at $100 \mathrm{~km}$ distance (double that if the $0.5^{\circ}$ gradation is used for the accuracy). While inexpensive and easy to use, there are potential sources of error involving its use, such as holding the device steady and level, or reporting percent grade instead of degrees (the device's dual display shows both degree inclination on the left and percent grade on the right leading to potential reporting error).

Figure 1 illustrates the technique used to measure the smoke plume height based on the measured inclinometer angle. Taking the curvature of the Earth into account, the equation for the smoke plume height, $\Delta z$, is

$\Delta z=\left(R_{\mathrm{E}}+z_{\mathrm{T}}\right)[\cos \phi+\tan (\phi+\varphi) \sin \phi]-R_{\mathrm{E}}-z_{\mathrm{f}}$,

where the horizon angle $\phi$ is

$\phi=D /\left(R_{\mathrm{E}}+z_{\mathrm{T}}\right)$

and $D$ is the distance from the tower to the fire, $R_{\mathrm{E}}$ is the radius of the Earth $(6371 \mathrm{~km}), z_{\mathrm{T}}$ is the tower elevation, $z_{\mathrm{f}}$ is the fire elevation, and $\varphi$ is the angle from the horizontal to the top of the plume as measured by the inclinometer.

Observers were asked to report equilibrium and maximum plume heights based on the plume's final levelling height and the maximum lofting height, respectively (Fig. 2). Due to buoyancy, a smoke plume will rise through the atmosphere until it reaches thermal equilibrium with the environment, typically spreading out laterally at this level. This is reported as the equilibrium height. Yet as it rises, the plume builds vertical velocity and thus will overshoot the equilibrium level, only to fall to the equilibrium level afterwards. This overshoot is reported as the maximum plume height. 


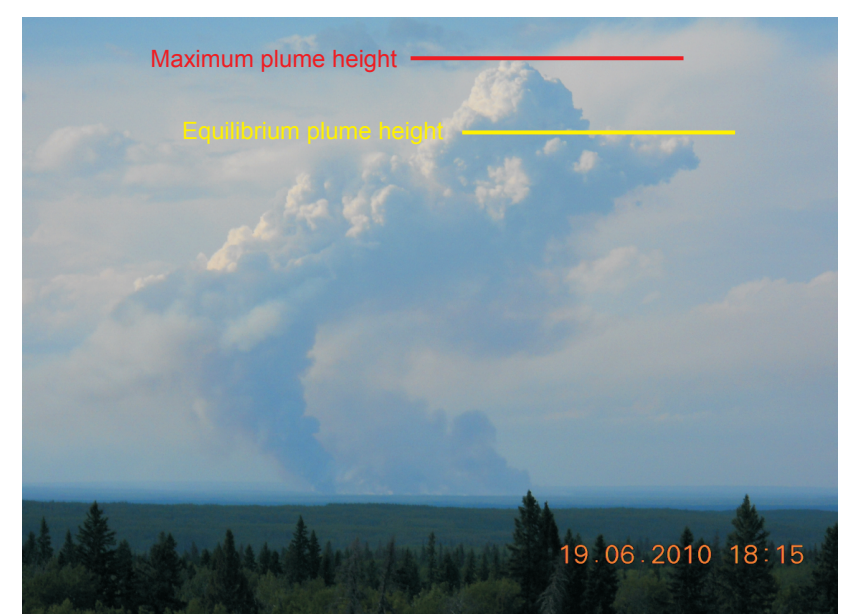

Figure 2. Illustration of the equilibrium and maximum plume heights for observation. Zoomed-in photo taken from the Whitefish lookout tower on 19 June 2010.

In addition to the inclinometer measurements, the observers were asked to photograph the plume with and without the zoom feature. This gave the authors a rudimentary ability to assess the quality of the observations.

\subsection{Fire assessment reports}

As fires are detected and actioned by fire-fighting resources, the province collects assessment data on the fire. Information includes the fire name and location, time and date of detection, the assessed size at the time when fire-fighting resources arrive, size and date at times of containment and of extinguishment, and several intermediate points. Additional information such as cause, fire characteristics and the fuel type are collected by teams at the fire location. These reports are tabulated annually at the Alberta Provincial Forest Fire Centre. Note that these reports are collected independently of the plume observations in this study.

For this study, plumes were matched with fire reports based on the time, date, and azimuth from the lookout tower. Distances to the fires and ground elevation above sea level at the fire locations were then determined.

\subsection{Fire weather conditions}

Fire weather conditions were obtained from the Canadian Wildland Fire Information System (Lee et al., 2003). Started in 1995, the CWFIS is a fire information system that monitors fire danger conditions across Canada. Daily noon weather conditions are collected from over 2500 federal and provincial weather stations, which are used to calculate daily Canadian Forest Fire Weather Index (FWI) System indices across Canada (Van Wagner, 1987). These indices are then used to produce gridded fire weather and fire behaviour maps based on the Canadian Forest Fire Danger Rating System
(CFFDRS) (Stocks et al., 1989). The CWFIS also collects and maps satellite-detected hotspots to monitor fire activity, models daily fire growth, maps reported fire locations, provides national situation reports, and hosts a data warehouse of historical fire perimeters for all of Canada. The CWFIS can be accessed at http://cwfis.cfs.nrcan.gc.ca/ during the fire season.

Weather conditions at each plume location were interpolated from the gridded CWFIS maps using an inverse distance weighting scheme. These included noon values of the temperature, relative humidity, wind speed and direction, and precipitation over the past $24 \mathrm{~h}$. Fire weather indices tracked by the CWFIS were similarly interpolated. These included the Fine Fuel Moisture Code (FFMC), Duff Moisture Code (DMC), Drought Code (DC), Initial Spread Index (ISI), Buildup Index (BUI), Fire Weather Index (FWI), and Daily Severity Rating (DSR) (Van Wagner, 1987).

\subsection{Forest fuel type}

A forest fuel type, a classification based on tree species and vegetative ground cover used to predict potential fire behaviour in the CFFDRS, was selected for each plume based on the priority approach. In Canada, the forest protection agencies of the provinces, territories, and national parks are responsible for fire management and fuel-type mapping. Fuels are mapped from various sources, typically forest inventory, Landsat imagery, or a combination of the two. A fuels map used in this study was provided by Alberta Agriculture and Forestry at $100 \mathrm{~m}$ resolution. The CWFIS also manages a national fuel-type map, which is based on satellite image-based land cover classification of Canada (Pouliot et al., 2012), ecozones and ecoregions of Canada (Ecological Stratification Working Group, Canada), the National Fire Database and National Burned Area Composite, provincial forest inventories and ecological stratification maps where publicly available to identify additional vegetation types, and Canada's forest inventory (Power and Gillis, 2006). In terms of priority, the first choice of fuel type was based on what was recorded in the provincial fire assessment reports. In some cases, this information was missing or deemed inappropriate for this study (e.g., a grass fire), in which case the provincial fuel map was used. If this information was missing (e.g., outside the province) or inappropriate, the CWFIS map was used.

\subsection{Fire behaviour characteristics}

Fire behaviour conditions presented in the study were calculated using the Canadian Fire Behaviour Prediction (FBP) System (Forestry Canada Fire Danger Group, 1992) of the CFFDRS, based on the interaction of fire weather and fuel type. System values examined in this study included the rate of spread (ROS, $\mathrm{m} \mathrm{min}^{-1}$ ), the crown fraction burned $(\mathrm{CFB}, \%)$, head fire intensity (HFI, $\mathrm{kW} \mathrm{m}^{-1}$ ), and the sur- 
face and total fuel consumptions ( $\mathrm{SFC}$ and TFC, $\mathrm{kg} \mathrm{m}^{-2}$ ). In most cases, $\mathrm{C} 2$ boreal spruce was used as the FBP fuel type.

Values for the area burned at the time of plume observations were derived from fire sizes at the time of assessment from the fire assessment reports (for example, an adjustment of the fire size must be made when a fire assessed at 14:00 MDT and the plume is observed at 15:00 MDT). Fires typically follow a diurnal growth cycle peaking in the late afternoon and subsiding overnight; hence, the fires in this study were assumed not to grow between 20:00 and 06:00 MDT of the next day; sizes could then be used for adjacent dates if required or deemed appropriate (e.g., a fire size reported late in the evening could be used as the fire size for a plume observation early the next day). For large, multi-day fires, sizes were based on fire mapping techniques using infrared satellite imagery from polar-orbiting satellites with the Moderate Resolution Imaging Spectroradiometer sensor (Englefield et al., 2004; Anderson et al., 2009). Finally, fire size was then adjusted from the assessed time to the plume observation time using elliptical fire growth (Forestry Canada Fire Danger Group, 1992). Fires tend to grow in elliptical shapes and, given the rate of spread (i.e., the velocity) of the fire, one can estimate the change in fire shape and size over time. For this study, these equations were applied in reverse to derive a time of ignition (when the fire size is zero) or 06:00 MDT for larger, multi-day fires and then recalculated forward in time to the plume observation time.

Based on the daily area growth and fuel consumption, the energy of the fire was calculated as

$Q=H w A$,

where $Q$ is the energy released by the fire (J), $H$ is the heat of combustion of wood $\left(1.8 \times 10^{7} \mathrm{~J} \mathrm{~kg}^{-1}\right)$, $w$ is the weight of fuel consumed $\left(\mathrm{kg} \mathrm{m}^{-2}\right)$, and $A$ is the area burned $\left(\mathrm{m}^{2}\right)$. This is a variation of Byram's fire line intensity equation (Byram, 1959), with rate of spread being replaced by area burned to provide the energy released.

It is important to note that not all of a fire's energy enters the buoyant plume. Large amounts of energy are spent propagating the fire forward (heating the fuel ahead of the fire and evaporating moisture), as well as being injected into the ground (released into the atmosphere but at a time much later than the primary plume development).

\section{Results}

\subsection{Plume observations}

The Alberta smoke plume observation study data provide the smoke plume observations for the Alberta smoke plume study, as well as information on the associated fire and observing station. During the study, 222 observation reports were collected. One report (plume observation 10) was a blend of two observations and thus was separated (10a, 10b); one report (204) was a duplicate (of 203). Of the remaining reports, 14 observations were rejected:

- three had no associated reported wildland fires $(29,30$, $50)$,

- one fire in neighbouring Saskatchewan had no certain fire report (21),

- five had camera malfunctions $(111,112,113,114,115)$, and

- five had poor observation conditions due to looking into the $\operatorname{Sun}(181,182,183,184,185)$.

Of the remaining 208 observed plumes, eight adjusted plume heights following Eq. (1) were negative $(2,44,59,65,74$, $76,83,117)$. These were also rejected and the final number of acceptable plume observations used in the study was 200 .

Table 2 summarizes statistics on the observed plumes. Excluding negative plume heights, there were 197 observed equilibrium plumes and 158 maximum plume heights $(4,66$, and 214 were missing equilibrium height but had maximum height observations, while 42 were missing maximum height observations). Observed equilibrium plume heights varied from 27 to $8833 \mathrm{~m}$, while maximum heights varied from 286 to $10540 \mathrm{~m}$. The distance at which plumes were observed from towers ranged from 3.6 to $173 \mathrm{~km}$. The time when plumes were observed varied from 08:46 to 21:30 MDT.

The distribution of plume heights (Fig. 3) shows the majority of equilibrium heights are below $2000 \mathrm{~m}$, while the majority of maximum heights are more broadly distributed up to $7500 \mathrm{~m}$. The ratio of maximum height over equilibrium for paired observations indicates that on average the maximum height was 3.8 times higher than the equilibrium height.

There were 60 reported fires in the study (some over multiple days) and 88 days with plume observations (87 with equilibrium heights, 64 with maximum heights). There were 39 cases of plumes being observed multiple times over the course of the day. For example, on 28 June 2015, fire LWF161 was observed 11 times from 14:05 to 18:30 MDT. To reduce possible bias, the subset of 88 observations (48 of single and 40 of multiple observations) was used to create a set of daily peak equilibrium and maximum plume heights. The benefit of such a subset is that it reflects the intended conditions of the fire weather measurements, that is of conditions at the time of peak burning (typically at 17:00 LST). Also, by selecting the peak values, any indirect problems, such as changes in afternoon weather or the impact of fire suppression efforts, are avoided.

Finally, there were six cases where two towers reported the same plume at approximately the same time (Table 3): SWF120 on 22 June 2010, PWF068 on 11 July 2012, GBZ002 on 6 August 2014, LWF161 on 24 June 2015, and PWF131 on 2 July and again on 19 July 2015. An examination of these cases helps to quantify the uncertainty of all observations in this study. 
Table 2. A summary of plume observation statistics.

\begin{tabular}{lrrrrrr}
\hline Variable & Min. & Median & Mean & Max. & SD & $N$ \\
\hline Equilibrium height (m) & 27 & 1105 & 1641 & 8833 & 1621 & 197 \\
Maximum height (m) & 286 & 3006 & 3643 & 10540 & 2321 & 158 \\
Ratio (Maximum/Equilibrium) & 1.0 & 2.4 & 3.8 & 36.8 & 4.4 & 155 \\
Distance (km) & 3.6 & 44.3 & 58.3 & 173.4 & 38.3 & 200 \\
Time & $08: 46$ & $16: 40$ & $16: 13$ & $21: 30$ & $02: 20$ & 200 \\
\hline
\end{tabular}

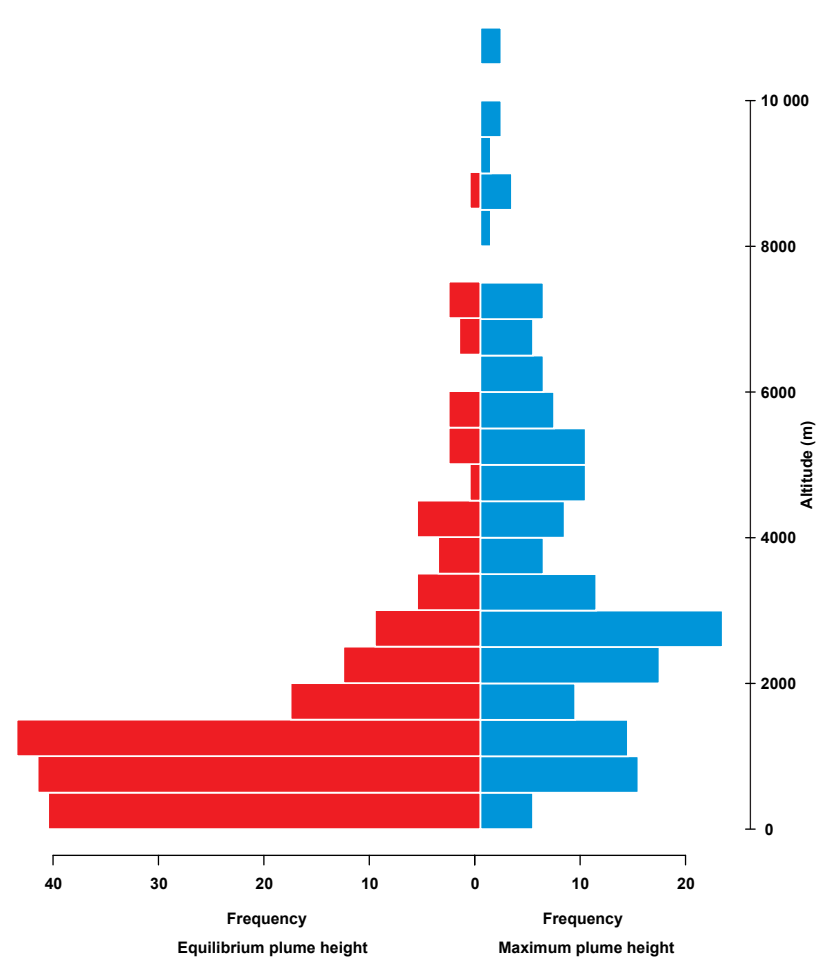

Figure 3. Histogram of equilibrium and of maximum plume heights (m).

On 22 June 2010, Trout Mountain and Teepee Lake both observed the plume from fire SWF120 (from 72 and $94 \mathrm{~km}$, respectively). Trout Mountain reported an equilibrium height of $4210 \mathrm{~m}$ at 16:30 (with a maximum height of $6727 \mathrm{~m}$ ) while equilibrium heights reported from Teepee Lake were $1927 \mathrm{~m}$ at 14:01 and 14:04 and $2058 \mathrm{~m}$ at 14:14. Given the $2 \mathrm{~h}$ difference in observation times, a comparison between the two towers is not appropriate.

On 11 July 2012, the plume from fire PWF068 was observed by both Hotchkiss and by Saddle Hills lookouts (from 23 and $173 \mathrm{~km}$, respectively). At 16:55 and again at 17:22, Hotchkiss reported a height of $1677 \mathrm{~m}$ with maximum heights of $4599 \mathrm{~m}$ and then $7440 \mathrm{~m}$. Saddle Hills reported a height of $5358 \mathrm{~m}$ and a maximum height of $6875 \mathrm{~m}$ at 16:12 and again at 16:58. Given the disparity in distances from the fire, the Hotchkiss observations are likely the most accurate and Saddle Hills was perhaps mistaking the maximum plume heights as the equilibrium. If so, the 16:58 Saddle Hills observation is a $16 \%$ overestimate of the 16:55 Hotchkiss observation and falls within the range of Hotchkiss observations between 16:55 and 17:22. Figure 4 shows the evolution of the plume as observed by the two towers. It appears that maximum heights are in general agreement but that Saddle Hills is likely measuring an erroneous equilibrium height. Figure 5 shows photos of the plume from Hotchkiss and from Saddle Hills at 16:54 and 16:58 (according to the uncalibrated clock times), illustrating the difficulties facing the observers and the resulting disparity in plume observations.

Similar comparisons can be drawn for the other cases. Fire GBZ002 was observed on 6 August 2014 by Pinto $(40 \mathrm{~km})$ and by Saddle Hills $(89 \mathrm{~km})$. Again, from a further distance it may be that the Saddle Hills observer mistook the equilibrium plume height (2967 $\mathrm{m}$ at 19:33) with the maximum observed by Pinto tower (2286 $\mathrm{m}$ at 19:36) and, if so, overestimated it by $30 \%$. Observations of fire LWF161 reported by Heart Lake $(76 \mathrm{~km})$ and May $(27 \mathrm{~km})$ towers coincided at 18:35, 24 June 2015. Equilibrium heights of 819 and 613 were within range of the device accuracy (33\% overestimate), but May observed an incredible maximum plume height $9.5 \mathrm{~km}$ a.g.l. not observed by Heart Lake. Fire PWF131 was reported by two towers on 2 July 2015 and again on 19 July by White Mountain $(112 \mathrm{~km})$ and Saddle Hills $(132 \mathrm{~km})$. On 2 July, both towers reported observations at 18:00 with Saddle Hills reporting equilibrium/maximum heights of 3808/7272 $\mathrm{m}$ and White Mountain reporting 3129/5088 $\mathrm{m}$, suggesting an overestimate of 21 and $43 \%$ by Saddle Hills. On 19 July, Saddle Hills reported equilibrium/maximum heights of $3808 / 4962 \mathrm{~m}$ at $17: 53$, while White Mountain reported 2151/3129 $\mathrm{m}$ at $18: 15$ growing to $4108 / 5088 \mathrm{~m}$ by 19:10. Comparing the first reports ( $22 \mathrm{~min}$ apart), Saddle Hills estimated plumes 77 and $58 \%$ higher, although the maximum height observed by White Mountain 55 min later exceeded the Saddle Mountain observation by only $2.5 \%$.

In summary, if we assume that Saddle Hills mistook maximum plume heights for equilibrium heights for fires PWF068 and GBZ-002, the overpredictions range from 16 to $77 \%$ for the equilibrium heights and 43 to $58 \%$ for the maximum heights. The average overprediction for equilibrium heights is $33 \%$ based on five cases and $51 \%$ for maximum heights based on two cases. 
Table 3. Multiple tower observations.

\begin{tabular}{|c|c|c|c|c|c|c|c|c|}
\hline Observation & $\begin{array}{l}\text { Fire } \\
\text { number }\end{array}$ & Tower & $\begin{array}{r}\text { Distance } \\
(\mathrm{km})\end{array}$ & $\begin{array}{r}\text { Device } \\
\text { Accuracy } \\
(\mathrm{m})\end{array}$ & $\begin{array}{l}\text { Date } \\
\text { (DD-MM-YYYY) }\end{array}$ & $\begin{array}{l}\text { Time } \\
\text { (MDT) } \\
(\mathrm{m})\end{array}$ & $\begin{array}{r}\text { Equilibrium } \\
\text { height } \\
(\mathrm{m})\end{array}$ & $\begin{array}{r}\text { Maximum } \\
\text { height }\end{array}$ \\
\hline 5 & SWF120 & Trout Mountain & 71.62 & \pm 314 & $22-06-2010$ & $16: 30$ & 4210 & 6727 \\
\hline 16 & SWF120 & Teepee Lake & 93.84 & \pm 410 & $22-06-2010$ & $14: 01$ & 1927 & \\
\hline 17 & SWF120 & & & & & $14: 04$ & 1927 & \\
\hline 18 & SWF120 & & & & & $14: 14$ & 2058 & \\
\hline 33 & PWF068 & Hotchkiss & 23.45 & \pm 103 & $11-07-2012$ & $8: 46$ & 1472 & 2089 \\
\hline 34 & PWF068 & & & & & $10: 41$ & 1266 & 2710 \\
\hline 35 & PWF068 & & & & & $13: 19$ & 1266 & 3753 \\
\hline 36 & PWF068 & & & & & $16: 55$ & 1677 & 4599 \\
\hline 37 & PWF068 & & & & & $17: 22$ & 1677 & 7440 \\
\hline 51 & PWF068 & Saddle Hills & 173.4 & \pm 758 & $11-07-2012$ & $16: 12$ & 5358 & 6875 \\
\hline 52 & PWF068 & & & & & $16: 58$ & 5358 & 6875 \\
\hline 53 & PWF068 & & & & & $19: 41$ & 6875 & 8393 \\
\hline 90 & GBZ002 & Pinto & 39.52 & \pm 172 & 06-08-2014 & $18: 34$ & 559 & 904 \\
\hline 91 & GBZ002 & & & & & $19: 36$ & 904 & 2286 \\
\hline 92 & GBZ002 & & & & & $20: 24$ & 904 & 2979 \\
\hline 93 & GBZ002 & & & & & $21: 30$ & 904 & 2979 \\
\hline 102 & GBZ002 & Saddle Hills & 88.99 & \pm 389 & 06-08-2014 & $19: 31$ & 2967 & 5304 \\
\hline 103 & GBZ002 & & & & & $19: 33$ & 2967 & 5304 \\
\hline 179 & LWF161 & Heart Lake & 76.01 & \pm 332 & $24-06-2015$ & $18: 35$ & 819 & 1217 \\
\hline 186 & LWF161 & May & 25.63 & \pm 112 & 24-06-2015 & 18:07 & 165 & 613 \\
\hline 187 & LWF161 & & & & & $18: 11$ & 165 & 2409 \\
\hline 188 & LWF161 & & & & & $18: 22$ & 613 & 4688 \\
\hline 189 & LWF161 & & & & & $18: 23$ & 613 & 5618 \\
\hline 190 & LWF161 & & & & & $18: 24$ & 1,061 & 6562 \\
\hline 191 & LWF161 & & & & & $18: 28$ & 1,509 & 8504 \\
\hline 192 & LWF161 & & & & & $18: 35$ & 613 & 9508 \\
\hline 193 & LWF161 & & & & & $19: 23$ & 1,061 & 10538 \\
\hline 194 & LWF161 & & & & & $19: 31$ & 1,509 & 10538 \\
\hline 150 & PWF131 & Saddle Hills & 132 & \pm 577 & 02-07-2015 & $17: 31$ & 4500 & 6116 \\
\hline 151 & PWF131 & & & & & $17: 34$ & 4500 & 6116 \\
\hline 152 & PWF131 & & & & & $18: 00$ & 3808 & 7272 \\
\hline 156 & PWF131 & White Mountain & 112.4 & \pm 489 & 02-07-2015 & $17: 25$ & 3129 & 4696 \\
\hline 157 & PWF131 & & & & & $17: 45$ & 4108 & 6068 \\
\hline 158 & PWF131 & & & & & $18: 00$ & 3129 & 5088 \\
\hline 159 & PWF131 & & & & & $18: 30$ & 3129 & 6068 \\
\hline 155 & PWF131 & Saddle Hills & 132 & \pm 577 & $19-07-2015$ & $17: 53$ & 3808 & 4962 \\
\hline 160 & PWF131 & White Mountain & 112.4 & \pm 489 & $19-07-2015$ & $18: 15$ & 2151 & 3129 \\
\hline 161 & PWF131 & & & & & $18: 20$ & 2151 & 3129 \\
\hline 162 & PWF131 & & & & & $18: 25$ & 2151 & 5088 \\
\hline 163 & PWF131 & & & & & $19: 10$ & 4108 & 5088 \\
\hline
\end{tabular}

\subsection{Fire weather conditions}

Fire weather conditions were sampled at all 200 plume locations. Because these weather values represent noon conditions, a subset of data limited to the 88 plume observation days was created. This provided 88 fire weather values, valid at noon each day.
A summary of the statistics of fire weather conditions associated with the plumes is shown in Table 4. This table shows that the mean noon weather conditions associated with smoke plumes reflect a typical summer day in Alberta with a temperature of $21.2^{\circ} \mathrm{C}$ and relative humidity of $37.7 \%$ with a wind speed of $13.4 \mathrm{kmh}^{-1}$.

Linear regressions were conducted to test for any relationships between plume heights and fire weather condi- 
PWF068 - 11 July 2012

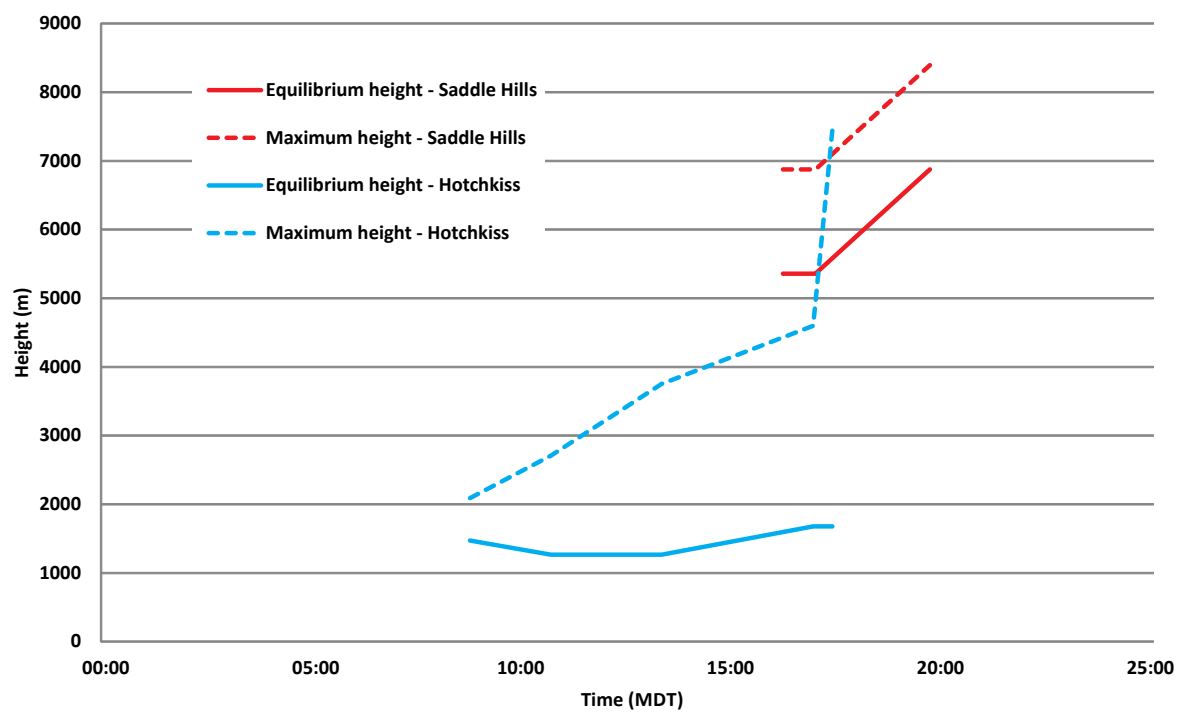

Figure 4. Evolution of observed plume heights for PWF068 from Hotchkiss at $24 \mathrm{~km}$ (blue) and from Saddle Hills at $173 \mathrm{~km}$ (red).

Table 4. A summary of weather and fire weather characteristics.

\begin{tabular}{lrrrrrr}
\hline Variable & Min. & Median & Mean & Max. & SD & $N$ \\
\hline Temperature $\left({ }^{\circ} \mathrm{C}\right)$ & 8.4 & 20.6 & 21.2 & 30.2 & 4.6 & 88 \\
Relative humidity $(\%)$ & 15.1 & 35.2 & 37.7 & 75.0 & 11.9 & 88 \\
Wind speed $\left(\mathrm{km} \mathrm{h}^{-1}\right)$ & 5.2 & 12.2 & 13.4 & 35.7 & 6.0 & 88 \\
FFMC & 45.1 & 89.1 & 86.5 & 95.4 & 8.2 & 88 \\
DMC & 11.4 & 39.7 & 42.2 & 115.5 & 17.8 & 88 \\
DC & 33.4 & 310.4 & 308.7 & 547.2 & 111.5 & 88 \\
ISI & 0.9 & 7.7 & 9.0 & 48.1 & 6.6 & 88 \\
BUI & 11.2 & 57.0 & 59.4 & 142.3 & 22.9 & 88 \\
FWI & 2.6 & 19.2 & 20.7 & 67.1 & 11.6 & 88 \\
DSR & 0.3 & 5.8 & 7.7 & 49.2 & 7.7 & 88 \\
\hline
\end{tabular}

FFMC is the Fine Fuel Moisture Code; DMC is the Duff Moisture Code; DC is the Drought Code; ISI is the Initial Spread Index; BUI is the Buildup Index; FWI is the Fire Weather Index; DSR is the Daily Severity Rating.

tions, comparing each of the variables in Table 4 individually against observed equilibrium and then maximum plume heights. Regressions were conducted first against all observations and then against the subset of 88 daily peak heights. No practical correlations were observed with the only $P$ value $<0.01$ for relative humidity $(0.0098)$ against the daily peak equilibrium height; all other $P$ values were $>0.05$.

\subsection{Fire behaviour characteristics}

Fire behaviour conditions were modelled for all 200 plumes; results are presented in Table 5. Unlike the noon-based fire weather, these values reflect conditions at the plume observation time, making each plume observation unique.

As was done with fire weather conditions, linear regressions were conducted to test for any relationships between plume heights and the fire behaviour variables listed in Table 5. Regressions were conducted first against all observations and then against the daily peak heights to remove bias resulting from multiple observations of the same plume (Table 6). Moving from fire weather to fire behaviour, clear correlations begin to emerge. Of these, total fuel consumption, hourly and daily growth, and energy of the fire consistently showed relationships with $\mathrm{P}$ values $<0.01$. There were weaker relationships between the remaining fire behaviour characteristics (rate of spread, head fire intensity, etc.) and plume height. In nearly all cases, scores were further improved when focusing on the daily peak heights.

Figure 6 shows a scatter plot of the energy of the fire (on a logarithmic scale) versus the daily peak equilibrium and maximum plume heights, presented to illustrate the degree of 
Table 5. A summary of fire behaviour characteristics.

\begin{tabular}{lrrrrrr}
\hline Variable & Min. & Median & Mean & Max. & SD & $N$ \\
\hline Daily growth (ha) & 0.005 & 11.5 & 290.9 & 10780.0 & 978.0 & 200 \\
Hourly growth (ha) & 0.0006 & 12.8 & 106.5 & 1506.0 & 248.1 & 200 \\
ROS $\left(\mathrm{m} \mathrm{min}^{-1}\right)$ & 0.0004 & 3.1 & 6.5 & 53.1 & 7.4 & 200 \\
SFC $\left(\mathrm{kg} \mathrm{m}^{-2}\right)$ & 0.10 & 2.28 & 2.21 & 6.24 & 1.15 & 200 \\
TFC $\left(\mathrm{kg} \mathrm{m}^{-2}\right)$ & 0.10 & 2.30 & 2.43 & 6.24 & 1.26 & 200 \\
HFI $\left(\mathrm{kW} \mathrm{m}^{-1}\right)$ & 0.06 & 2117 & 6159 & 56280 & 8129 & 200 \\
CFB $(\%)$ & 0 & 0 & 29 & 100 & 40 & 200 \\
$Q(\mathrm{~J})$ & $7.16 \times 10^{7}$ & $6.41 \times 10^{12}$ & $1.82 \times 10^{14}$ & $7.84 \times 10^{15}$ & $6.65 \times 10^{14}$ & 200 \\
\hline
\end{tabular}

ROS is the rate of spread; SFC is the surface fuel consumption; TFC is the total fuel consumption; HFI is the head fire intensity; CFB is the crown fraction burned; $Q$ is the energy release of the fire.

Table 6. Correlation of fire behaviour and observed plume heights.

\begin{tabular}{|c|c|c|c|c|c|c|c|c|}
\hline & \multicolumn{4}{|c|}{ All observations } & \multicolumn{4}{|c|}{ Daily peak heights } \\
\hline & \multicolumn{2}{|c|}{ Equilibrium } & \multicolumn{2}{|c|}{ Maximum } & \multicolumn{2}{|c|}{ Equilibrium } & \multicolumn{2}{|c|}{ Maximum } \\
\hline & $r^{2}$ & $N$ & $r^{2}$ & $N$ & $r^{2}$ & $N$ & $r^{2}$ & $N$ \\
\hline Daily growth (ha) & $0.153^{\mathrm{b}}$ & 197 & $0.119^{\mathrm{b}}$ & 158 & $0.203^{b}$ & 87 & $0.144^{\mathrm{b}}$ & 64 \\
\hline Hourly growth (ha) & $0.094^{b}$ & 197 & $0.116^{\mathrm{b}}$ & 158 & $0.148^{b}$ & 87 & $0.141^{\mathrm{b}}$ & 64 \\
\hline $\operatorname{ROS}\left(\mathrm{mmin}^{-1}\right)$ & $0.036^{\mathrm{b}}$ & 197 & $0.105^{\mathrm{b}}$ & 158 & 0.025 & 87 & $0.119^{\mathrm{b}}$ & 64 \\
\hline $\operatorname{SFC}\left(\mathrm{kg} \mathrm{m}^{-2}\right)$ & 0.013 & 197 & 0.018 & 158 & $0.058^{\mathrm{a}}$ & 87 & $0.068^{\mathrm{a}}$ & 64 \\
\hline $\operatorname{TFC}\left(\mathrm{kg} \mathrm{m}^{-2}\right)$ & $0.037^{b}$ & 197 & $0.050^{\mathrm{b}}$ & 158 & $0.085^{\mathrm{b}}$ & 87 & $0.106^{\mathrm{b}}$ & 64 \\
\hline $\mathrm{HFI}\left(\mathrm{kW} \mathrm{m}^{-1}\right)$ & $0.030^{\mathrm{a}}$ & 197 & $0.088^{b}$ & 158 & 0.031 & 87 & $0.136^{\mathrm{b}}$ & 64 \\
\hline $\mathrm{CFB}(\%)$ & 0.001 & 197 & $0.126^{\mathrm{b}}$ & 158 & 0.002 & 87 & 0.109 & 64 \\
\hline $\log _{10}(Q(\mathrm{~J}))$ & $0.081^{b}$ & 197 & $0.124^{b}$ & 158 & $0.171^{b}$ & 87 & $0.137^{\mathrm{b}}$ & 64 \\
\hline
\end{tabular}

a $P$ value $<0.05 ;$ b $P$ value $<0.01$

ROS is the rate of spread; SFC is the surface fuel consumption; TFC is the total fuel consumption; HFI is the head fire intensity; CFB is the crown fraction burned; $Q$ is the energy release of the fire.

scatter in the data set. The regression lines through the data provide coefficients of determination $\left(r^{2}\right)$ values of 0.171 and 0.137 , respectively. Additional relationships could be drawn through these data but the intent of the work at this stage is simply to validate the confidence in core physical relations (in this case, $P=0.00007$ and 0.00259 , respectively). Further analyses have been left for a future plume-rise model and are outside the scope of this study.

\section{Discussion}

The project set out to collect smoke plume heights as observed from lookout towers in Alberta. Already trained in recognizing smoke plumes for fire detection purposes, observers were asked to measure, photograph, and document the plume heights they saw. In principle, this seemed a logical method to collect plume observations, yet many unanticipated issues arose as the project developed.

Observation errors were possibly the largest source of error in this study. It was apparent from the written reports that not all information was complete or accurate. Given the oc- casional wrong dates or missing times scattered throughout the reports, one can assume that errors in reported inclinations would also be embedded in the reports, whether due to reading the device improperly or incorrectly copying the data. This assumption is supported by the seven cases of negative plume heights when calculated using Eq. (1) and the observed inclinations. Determining which observations were in error was not possible.

As the observer from Keg Tower wrote, "I was able to use it [the inclinometer] on two smokes/fires but they were fairly small and distant so there was not much height difference from my location to the smoke plume height and I found it difficult to hold the inclinometer steady enough for a really accurate reading".

Another source of systematic error lies in the subjectiveness of plume observations. This is apparent when considering that on average the maximum heights were nearly 4 times higher than the equilibrium, which seems greater than would be expected. While the plume characteristics and reporting techniques were described to the observers, precisely how the observers judged these levels comes into question. A significant source of this uncertainty lies in the fact that what one 


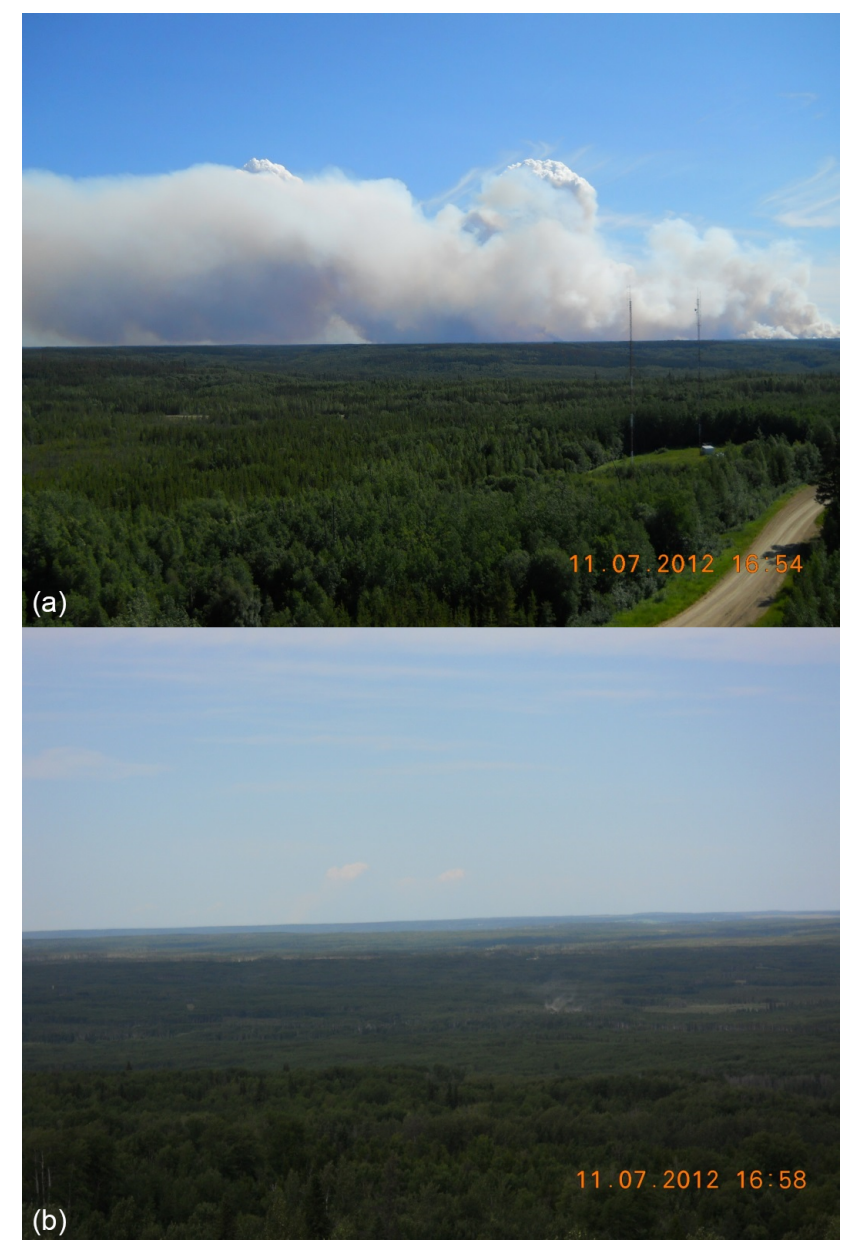

Figure 5. Zoomed-out photograph of plume from fire PWF068 from Hotchkiss at $24 \mathrm{~km}$ (a) and zoomed-in from Saddle Hills at $173 \mathrm{~km}$ (b).

observer may see as an equilibrium plume height another observer may believe to be a maximum height, especially when one observation is close to the plume and a second observer is distant and unable to see the lower equilibrium level. This was certainly the case for PWF068 in 2012 (Figs. 4, 5) and GBZ002 in 2014.

The perspective or point of view is also a concern. A smoke plume can look very different when viewed from close up or from afar, as was demonstrated by PWF068. The orientation of the plume is also associated with perspective. A plume approaching the viewer at an oblique angle or overhead creates a dilemma about where along the plume to assess the top and would likely result in a higher inclination being reported than for a plume viewed from the side. This might explain the excessive maximum plume heights of LWF191 observed by the May tower.

Finally, the clarity of the observations was also an issue. Observers were discouraged from reporting in hazy conditions or looking into the Sun (as noted by the observer for

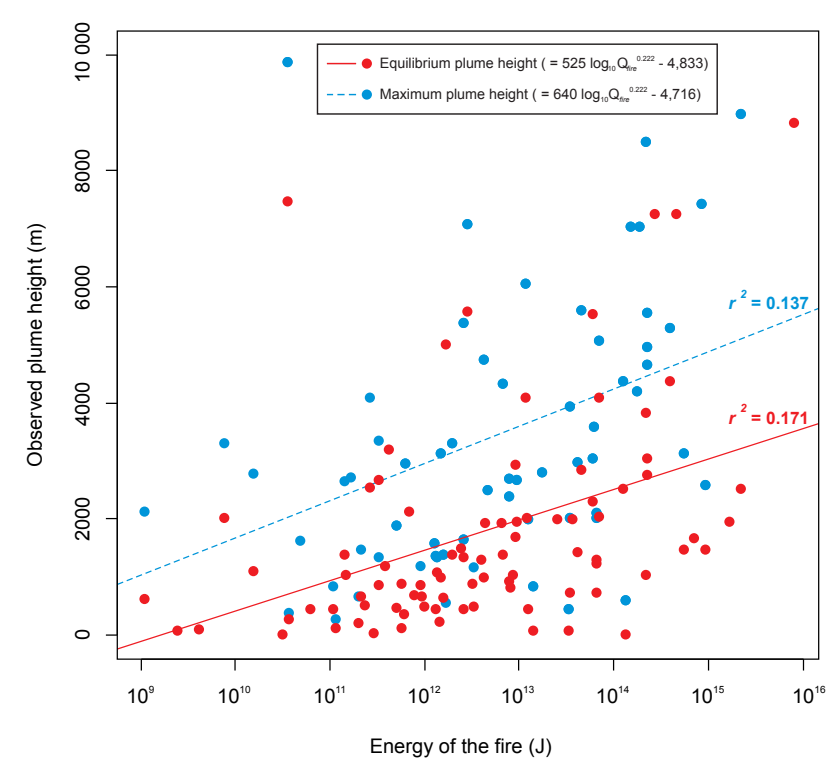

Figure 6. Energy of the fire $(\mathrm{J})$ on a logarithmic scale compared with observed equilibrium and maximum plume heights $(\mathrm{m})$. Correlation coefficients shown next to trend line; regression equations shown in the legend.

plume observations 181 to 185 ), but some observers may have persisted and reported questionable plumes - especially in the distance - or confused smoke plumes with cumulus clouds. Digital photographs were taken of each plume but in many cases the plumes were difficult to distinguish. In the future, photographs may need to be filtered or polarized to help in their clarity and usefulness.

In the case of the six plumes observed by two independent towers, the observed heights varied considerably with an average difference of about $40 \%$. In five of the six cases, the higher plume heights were reported by the more distant tower (excluding the maximum plume height of LWF161 observed by the May tower). It may be that, from a distance, plume heights were harder to define. There is also the question of the qualitative consistency and bias of the observations. For example, Saddle Hills consistently reported heights higher than the other towers, and the equilibrium heights reported by Saddle Hills were often close to the maximum heights observed by other towers. This may have been a bias due to the judgement of the observer, based on their assessment of what constituted a plume top.

Regardless of the issues presented above, evidence of a relationship emerged between observed plume heights and the fire behaviour parameters that would drive such a process. As noted on Table 6, the strongest relationships were with daily area burned, total fuel consumption, and energy of the fire. This follows the relationship described by Eq. (3) whereby the weight of the fuel consumed $(w)$ and the area growth $(A)$ lead to the energy of the fire $(Q)$. Given that plume height is buoyancy driven and tied to the energy of the fire, such 
a relationship is expected. Other factors involved in determining plume rise, such as atmospheric moisture, turbulence, and ambient lapse rate, are undetermined and therefore act against a stronger relationship appearing in this data set.

\section{Future work}

The purpose for collecting these data was to create an extensive data set composed of ground-based observations of smoke columns and related fire information to validate a plume-rise model the authors are developing (Anderson et al., 2011). This model calculates the energy released by the fire and predicts the penetration height following thermodynamic principles (including atmospheric stability as captured through upper-air profiles). Given the issues involved with the observations, it was deemed important to publish these results prior to conducting the validation study.

It is recommended that future studies of this nature use the lessons learned from this study to improve measurement procedures and technology, such as polarized filters for photography. Provincial agencies are also moving towards centralized fire detection using remote cameras in the forest. Accessing such photographic records could provide a more rigorous data set of plume observations. Another approach would be to employ cell phones along with GPS coordinates and calibrated angles of view. Given the ubiquity of cell phones, this would likely allow multiple views of the same fire at more frequent intervals.

Other studies have used remote sensing techniques to measure plume heights. Val Martin et al. (2012) use the spacebased Multi-angle Imaging SpectroRadiometer with its ability to view plumes three-dimensionally to obtain plume heights to evaluate a widely used plume model (Freitas et al., 2007). Raffuse et al. (2012) compared MISR plume predictions in the continental USA to those used in the BlueSky framework (Larkin et al., 2009). Combining MISR with ground-based plume observations could provide a robust data set for similar evaluations.

\section{Data availability}

The Alberta smoke plume observation study data can be found on the Canadian Wildland Fire Information System datamart (Natural Resources Canada, 2018) at http://cwfis. cfs.nrcan.gc.ca/datamart.

\section{Conclusions}

A project was conducted to measure smoke plumes from wildland fires in Alberta. This study used handheld inclinometer measurements and photos taken at lookout towers in the province. Observations of 222 plumes were collected from 21 lookout towers over a 6-year period from 2010 to 2015. Observers reported the equilibrium and maximum plume heights based on the plumes' final levelling heights and the maximum lofting heights, respectively.

Observations were tabulated at the end of each year and matched to reported fires. Fire weather conditions and forest fuel types were then obtained from the Canadian Wildland Fire Information System. Assessed fire sizes were adjusted to the appropriate size at plume observation time using elliptical fire-growth projections.

In principle, this seemed a logical method to collect plume observations, yet many unanticipated issues arose as the project developed. Instrument limitations and less-thanoptimal observing conditions challenged the observers. This, along with the expected likelihood of reporting errors, limited the quality of the final data. Regardless of the possible errors, this is still a very interesting and valuable data set. The data set showed that responses to fire behaviour conditions were consistent with the physical processes leading to plume rise and will be used in a future plume-rise model validation study.

The purpose for collecting these data was to create an extensive data set composed of ground-based observations of smoke columns and related fire information for the development of a wildfire plume-rise model. Our study indicates that this approach has potential but also that there are significant methodology issues to be overcome. It is our judgement that data from this study must be used judiciously with full knowledge of its shortcomings and should be supplemented with other data when confirming or supporting plume-rise models.

Competing interests. The authors declare that they have no conflict of interest.

Acknowledgements. We acknowledge Peter Englefield (Natural Resources Canada) for his assistance in collecting and sampling the CWFIS data as well as the outstanding work done by the managers and observers of Alberta Agriculture and Forestry, without whom this data set would not have been possible. Finally, we acknowledge Brian Wiens who helped conceive the idea of this project and who promoted its progress.

Edited by: Alexander Kokhanovsky

Reviewed by: two anonymous referees

\section{References}

Achtemeier, G. L., Goodrick, S. A., Liu, Y., Garcia-Menendez, F., $\mathrm{Hu}$, Y., and Odman, M. T.: Modeling smoke plume-rise and dispersion from southern United States prescribed burns with daysmoke, Atmosphere, 2, 358-388, 2011.

Anderson, K., Englefield, P., Little, J., and Reuter, G.: An approach to operational forest fire growth predictions for Canada, Int. J. Wildland Fire, 18, 893-905, https://doi.org/10.1071/WF08046, 2009 . 
Anderson, K., Pankratz, A., and Mooney, C.: 9.2 A thermodynamic approach to estimating smoke plume heights, in: Proceedings of Ninth Symposium on Fire and Forest Meteorology, Palms Springs, CA, 17-21 October 2011, AMS, Boston, MA, 2011.

Briggs, G.: A plume rise model compared with observations, JAPCA J. Air Waste Ma., 15, 433-438, https://doi.org/10.1080/00022470.1965.10468404, 1965.

Byram, G.: Combustion of forest fuels, in: Forest fire: control and use, edited by: Brown, A. A. and Davis, K. P., 61-89, McGrawHill, New York, 1959.

Ecological Stratification Working Group (Canada), Center for Land and Biological Resources Research (Canada), and Canada. State of the Environment Directorate: A national ecological framework for Canada, Centre for Land and Biological Resources Research; Hull, Quebec: State of the Environment Directorate, 1996.

Englefield, P., Lee, B., Fraser, R., Landry, R., Hall, R., Lynham, T., Cihlar, J., Li, Z., Jin, J., and Ahern, F.: Applying geographic information systems and remote sensing to forest fire monitoring, mapping, and modeling in Canada, in: Proceedings of the 22nd Tall Timbers Fire Ecology Conference: Fire in Temperate, Boreal and Montane Ecosystems, 240-245, 2004.

Flannigan, M. D., Krawchuk, M. A., de Groot, W. J., Wotton, B. M., and Gowman, L. M.: Implications of changing climate for global wildland fire, Int. J. Wildland Fire, 18, 483-507, 2009.

Forestry Canada Fire Danger Group: Development and Structure of the Canadian Forest Fire Behavior Prediction System, Tech. Rep. S-T-X-3, Forestry Canada, Science and Sustainable Development Directorate, 1992.

Freitas, S. R., Longo, K. M., Chatfield, R., Latham, D., Silva Dias, M. A. F., Andreae, M. O., Prins, E., Santos, J. C., Gielow, R., and Carvalho Jr., J. A.: Including the sub-grid scale plume rise of vegetation fires in low resolution atmospheric transport models, Atmos. Chem. Phys., 7, 3385-3398, https://doi.org/10.5194/acp7-3385-2007, 2007.

Goodrick, S., Achtemeier, G., Larkin, N., Liu, Y., and Strand, T.: Modelling smoke transport from wildland fires: A review, Int. J. Wildland Fire, 22, 83-94, https://doi.org/10.1071/WF11116, 2013.

Harrison, H. and Hardy, C.: Plume rise from gigawatt fires: observations and models, unpublished manuscript, available at: http://www.atmos.washington.edu/ harrison/reports/plume3. pdf (last access: 19 February 2018), 2002.

Heilman, W., Liu, Y., Urbanski, S., Kovalev, V., and Mickler, R.: Wildland fire emissions, carbon, and climate: plume rise, atmospheric transport, and chemistry processes, Forest Ecol. Manag., 317, 70-79, https://doi.org/10.1016/j.foreco.2013.02.001, 2014.

Kovalev, V. A., Petkov, A., Wold, C., Urbanski, S., and Hao, W. M.: Determination of smoke plume and layer heights using scanning lidar data, Appl. Optics, 48, 5287-5294, 2009.

Lareau, N. P. and Clements, C. B.: Environmental controls on pyrocumulus and pyrocumulonimbus initiation and development, Atmos. Chem. Phys., 16, 4005-4022, https://doi.org/10.5194/acp-16-4005-2016, 2016.

Larkin, N., O’Neill, S., Solomon, R., Raffuse, S., Strand, T., Sullivan, D., Krull, C., Rorig, M., Peterson, J., and Ferguson, S.: The BlueSky smoke modeling framework, Int. J. Wildland Fire, 18, 906-920, https://doi.org/10.1071/WF07086, 2009.

Larkin, N., Strand, T., Drury, S., Raffuse, S., Solomon, R., O’Neill, S., Wheeler, N., Huang, S., Roring, M., and Hafner, H.: Phase
1 of the Smoke and Emissions Model Intercomparison Project (SEMIP): creation of SEMIP and evaluation of current models, available at: https://digitalcommons.unl.edu/jfspresearch/42/ (last access: 19 February 2018), 2012.

Lavrov, A., Utkin, A. B., Vilar, R., and Fernandes, A.: Evaluation of smoke dispersion from forest fire plumes using lidar experiments and modelling, Int. J. Therm. Sci., 45, 848-859, 2006.

Lee, B., Alexander, M., Hawkes, B., Lynham, T., Stocks, B., and Englefield, P.: Information systems in support of wildland fire management decision making in Canada, Comput. Electron. Agr., 37, 185-198, https://doi.org/10.1016/S01681699(02)00120-5, 2003.

Liu, Y., Achtemeier, G. L., Goodrick, S. L., and Jackson, W. A.: Important parameters for smoke plume rise simulation with Daysmoke, Atmos. Pollut. Res., 1, 250-259, 2010.

Liu, Y., Goodrick, S. L., Achtemeier, G. L., Forbus, K., and Combs, D.: Smoke plume height measurement of prescribed burns in the south-eastern United States, Int. J. Wildland Fire, 22, 130-147, 2013.

Natural Resources Canada: Canadian Wildland Fire Information System, CWFIS Datamart, Natural Resources Canada: Ottawa, ON, available at: http://cwfis.cfs.nrcan.gc.ca/datamart, last access: 19 February 2018.

Pouliot, D., Latifovic, R., Olthof, I., and Fraser, R.: Supervised Classification Approaches for the Development of Land-Cover Time Series, in: Remote Sensing of Land Use and Land Cover: Principles and Applications, edited by: Giri, C. P., 177-190, CRC Press, Boca Raton FL, 2012.

Power, K. and Gillis, M.: Canada's forest inventory 2001, vol. 408, Pacific Forestry Centre, Victoria, BC, 2006.

Raffuse, S., Craig, K., Larkin, N., Strand, T., Sullivan, D., Wheeler, N., and Solomon, R.: An evaluation of modeled plume injection height with satellite-derived observed plume height, Atmosphere, 3, 103-123, https://doi.org/10.3390/atmos3010103, 2012.

Rolph, G. D., Draxler, R. R., Stein, A. F., Taylor, A., Ruminski, M. G., Kondragunta, S., Zeng, J., Huang, H.-C., Manikin, G., McQueen, J. T., et al.: Description and verification of the NOAA smoke forecasting system: the 2007 fire season, Weather Forecast., 24, 361-378, 2009.

Sofiev, M., Vankevich, R., Lotjonen, M., Prank, M., Petukhov, V., Ermakova, T., Koskinen, J., and Kukkonen, J.: An operational system for the assimilation of the satellite information on wildland fires for the needs of air quality modelling and forecasting, Atmos. Chem. Phys., 9, 6833-6847, https://doi.org/10.5194/acp9-6833-2009, 2009.

Sofiev, M., Ermakova, T., and Vankevich, R.: Evaluation of the smoke-injection height from wild-land fires using remote-sensing data, Atmos. Chem. Phys., 12, 1995-2006, https://doi.org/10.5194/acp-12-1995-2012, 2012.

Stieb, D., Yao, J., Henderson, S., Pinault, L., Smith-Doiron, M., Robichaud, A., van Donkelaar, A., Martin, R., Menard, R., and Brook, J. R.: Variability in ambient air pollution concentrations and population susceptibility among Canadian health regions, $\mathrm{C}$. J. Public Health, in review, 2018.

Stocks, B., Lawson, B., Alexander, M., Van Wagner, C., McAlpine, R., Lynham, T., and Dubé, D, E.: The Canadian Forest Fire Danger Rating System: an overview, Forest. Chron., 65, 450-457, 1989. 
Val Martin, M., Logan, J. A., Kahn, R. A., Leung, F.-Y., Nelson, D. L., and Diner, D. J.: Smoke injection heights from fires in North America: analysis of 5 years of satellite observations, Atmos. Chem. Phys., 10, 1491-1510, https://doi.org/10.5194/acp10-1491-2010, 2010.

Val Martin, M., Kahn, R., Logan, J., Paugam, R., Wooster, M., and Ichoku, C.: Space-based observational constraints for 1-D fire smoke plume-rise models, J. Geophys. Res.-Atmos., 117, published online, 18 pp., https://doi.org/10.1029/2012JD018370, 2012.
Van Wagner, C.: Development and structure of the Canadian Forest Fire Weather Index System, Tech. Rep. 35, Canadian Forestry Service, Ottawa, ON, 1987. 